EchoGéo

\title{
A post-apartheid landscape : the legacy of resettlement in Limpopo
}

\section{Kevin Cox}

\section{(2) OpenEdition}

\section{Journals}

Édition électronique

URL : https://journals.openedition.org/echogeo/12031

DOI : 10.4000/echogeo.12031

ISSN : 1963-1197

\section{Éditeur}

Pôle de recherche pour l'organisation et la diffusion de l'information géographique (CNRS UMR 8586)

\section{Référence électronique}

Kevin Cox, "A post-apartheid landscape : the legacy of resettlement in Limpopo », EchoGéo [En ligne], 13 | 2010, mis en ligne le 20 septembre 2010, consulté le 21 septembre 2021. URL : http:// journals.openedition.org/echogeo/12031; DOI : https://doi.org/10.4000/echogeo.12031

Ce document a été généré automatiquement le 21 septembre 2021.

EchoGéo est mis à disposition selon les termes de la licence Creative Commons Attribution - Pas d'Utilisation Commerciale - Pas de Modification 4.0 International (CC BY-NC-ND) 


\title{
A post-apartheid landscape : the legacy of resettlement in Limpopo
}

\author{
Kevin Cox
}

Illustration 1 - Limpopo province

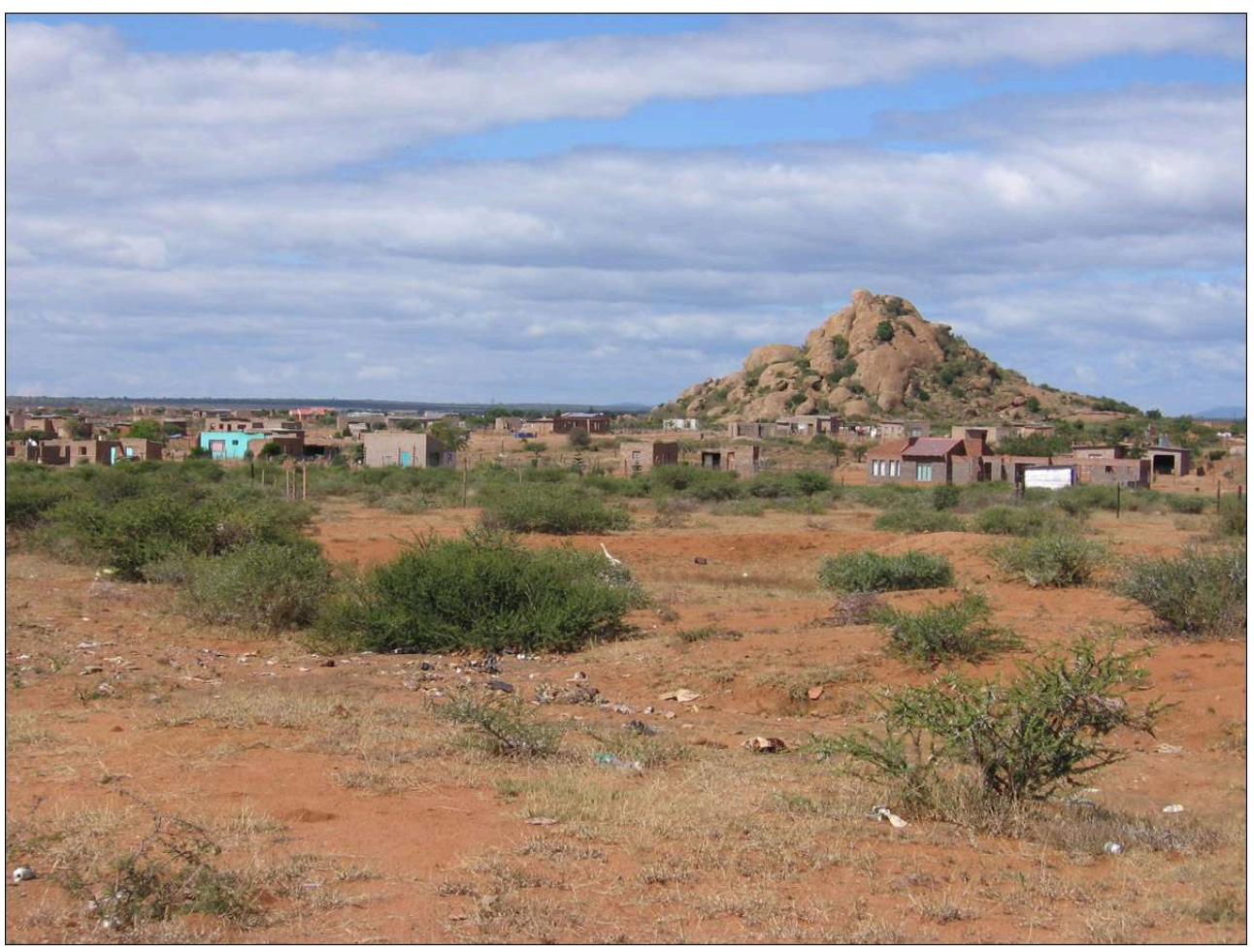

Auteur: Kevin Cox, 12 mai 2005.

1 The settlement shown here is located some thirty or so miles north of Polokwane in Limpopo province. Under apartheid it would have been a so-called "resettlement point". It would have then been in one of the so-called "homelands" and so one of the destinations for those South Africans whom the apartheid government aimed to "re- 
unite with their ethnic brothers". Originally the housing structures would have been very rudimentary, consisting mainly of corrugated iron. They have been improved over the years so that now they have concrete or brick walls. The fact that some are still in the course of improvement is also evident. Improvement has been in accordance with the flow of money through the area. For the most part this comes from migrant workers working in distant cities like Pretoria or Johannesburg, in mining areas or even on white commercial farms in Limpopo. Under apartheid their migratory status would have been enforced. Now they can choose to settle closer to their work if they wish to. It is significant that they have chosen to remain migrant workers and improve their housing in the former resettlement points. There are several reasons for this. One is the greater physical security for dependents compared to the big cities. Significant amounts of money have been invested in the housing and the market for them is poorly developed; so relocation would be at a considerable financial loss. In addition, lots are larger than in the city allowing keeping chickens and goats. As a result these sorts of settlement are likely to be a continuing feature of the South African landscape for a long time to come.

\section{BIBLIOGRAPHIE}

Allanic B., 2003. From dumping grounds to attractive residential settlements. In Recompositions territoriales, confronter et innover. Actes des rencontres scientifiques franco-sud africaines de l'innovation territoriale, Antheaume B., Giraut F. \& Maharaj B. (eds). http://www.pacte.cnrs.fr/ IMG/pdf_39_Allanic._Borderlands.1.pdf

Mac Carthy J. \& Bernstein A., 1998. South Africa's "Discarded people" : Survival ; adaptation and current challenges. Johannesburg, CDE (CDE Research. Policy in the Making 9).

Platzky L. \& Walker C., 1985. The Surplus People : Forced Removals in South Africa. Johannesburg, Ravan.

Ramutsindela M \& Donaldson R. (eds.), 2001. The Imprint of Bantustans and Transformation. The South African Geographical Journal, vol.83, №1.

\section{AUTEUR}

\section{KEVIN COX}

Ohio State University, Colombus, cox.13@osu.edu 